\title{
1. INTRODUCTION: BACKGROUND AND EXPLANATORY NOTES
}

\author{
Bruce P. Luyendyk, Department of Geological Sciences, UC Santa Barbara, Santa Barbara, California \\ J.R. Cann, Department of Geology, The University, Newcastle-upon-Tyne, United Kingdom \\ and \\ George S. Sharman, Scripps Institution of Oceanography, La Jolla, California ${ }^{1}$
}

\section{BACKGROUND AND OBJECTIVES}

Leg 49 of the International Phase of Ocean Drilling (IPOD) was designed with a wide spectrum of problems in mind. Topics investigated were (1) variation with time of mantle sources of spreading-center magmas, (2) aging of the volcanic layer, (3) degree of hydrothermal alteration and metamorphism of the volcanic layer, (4) lateral and vertical variation of the petrochemistry, magnetic properties, and structure of the volcanic layer, (5) north-south variability of spreading-center magmas through the North Atlantic, (6) initiation of glaciation during the late Pliocene, and (7) the influence of bottom currents originating at the Iceland-Faeroes Ridge on sediments of the ridge flank province of the western North Atlantic.

The igneous rock studies fall under two general categories. ${ }^{2}$ The first is crustal processes occurring at diverging boundaries now and during the geologically recent past. Important questions concerned with the igneous processes at plate boundaries include the chemistry of lava and its variability, and correlation with the factors that determine the structure and thickness of flow units and their magnetic and seismic properties. How do these data match values predicted by geophysical models? Certain questions regarding hydrothermal processes at ridge crests need study: Do the rocks show evidence of hydrothermal convection, and how is this process localized vertically and horizontally? What effects could hydrothermal convection have on the chemistry of sea water, and can it account for metalliferous deposits in the volcanic layer? Evidence from dredges and ophiolites suggests that metamorphism occurs periodically in the volcanic layer. By drilling, we seek evidence of metamorphism and its effects on the vertical stratigraphy.

A second category is temporal variation in the characteristics of the volcanic layer: How does old crust differ from young? Is there evidence for change in mantle-source chemistry over tens of millions of years? How important is hydrothermal activity in older crust? What are the weathering processes in the volcanic layer? How does aging affect the magnetic properties and seismic velocities of the volcanic layer?

Our drilling program included three holes $(407,408$, and 409 ) on the west flank of the Reykjanes Ridge and seven in the crestal regions of the Mid-Atlantic Ridge (Figure 1).

\footnotetext{
${ }^{1}$ Currently at Texas A\&M University, College of Geosciences, College Station, Texas.

${ }^{2}$ This section after OCP white paper.
}

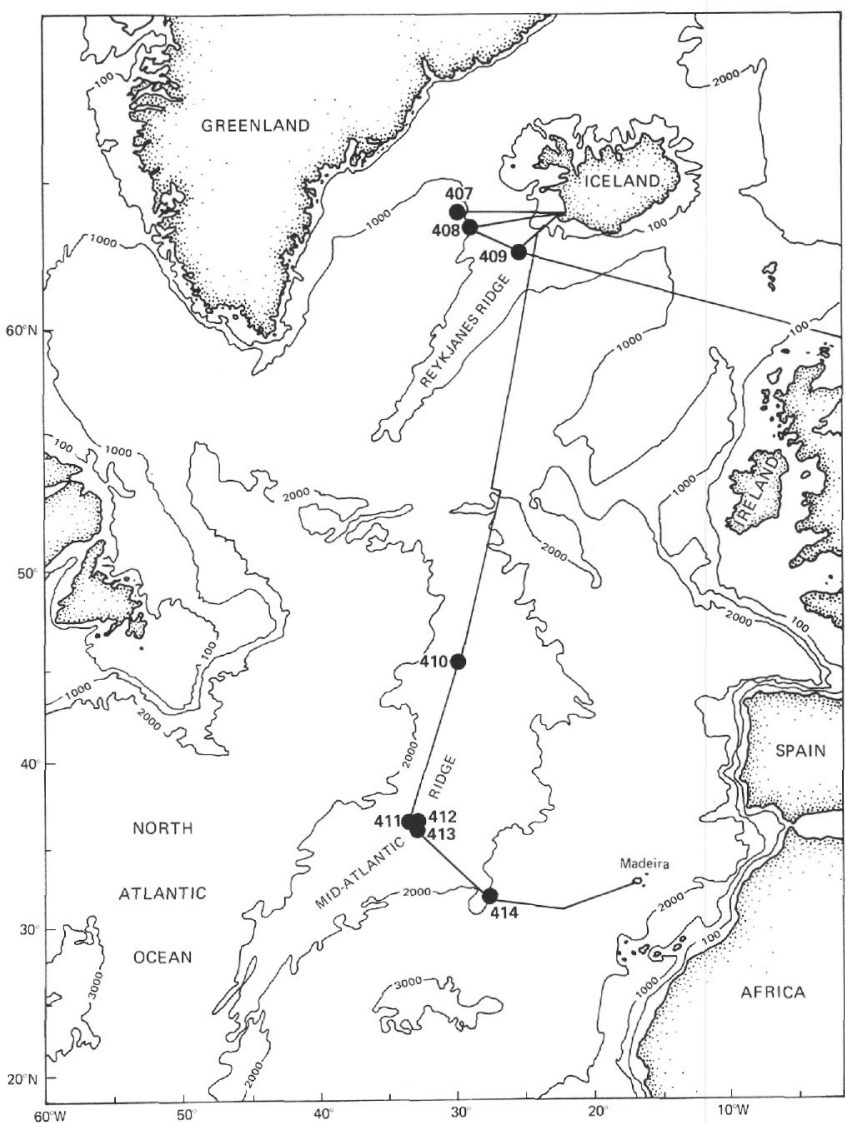

Figure 1. Sites drilled during DSDP Leg 49.

Single-bit drilling was thus done in a variety of geologic provinces in the North Atlantic. Downhole logging was not done. Also, an XRF was not available for this leg. On shipboard, we had available the usual petrologic and sedimentologic laboratory facilities. For measuring paleomagnetism, we had a Digico spinner, an alternating field demagnetizer, and a thermal demagnetizer. We made underway measurements using echo sounding $(12 \mathrm{kHz})$, magnetic field, and airgun reflection, and on-site we used wide-angle reflection (with sonobuoys).

The Reykjanes Ridge (RER) is on the boundary of the North American and European plates. It is a slow-spreading (one $\mathrm{cm} /$ year) oceanic ridge which trends southwest from Iceland and terminates against the Charlie Gibbs fracture zone at about $53^{\circ} \mathrm{N}$. It differs from other slow-spreading ridges in that it does not have a well-defined rift valley at its crest (Talwani et al., 1971). From latitudes $61^{\circ}$ to $64^{\circ} \mathrm{N}$, the ridge crest is about $50 \mathrm{~km}$ wide and $1 \mathrm{~km}$ high (Figure 2). 


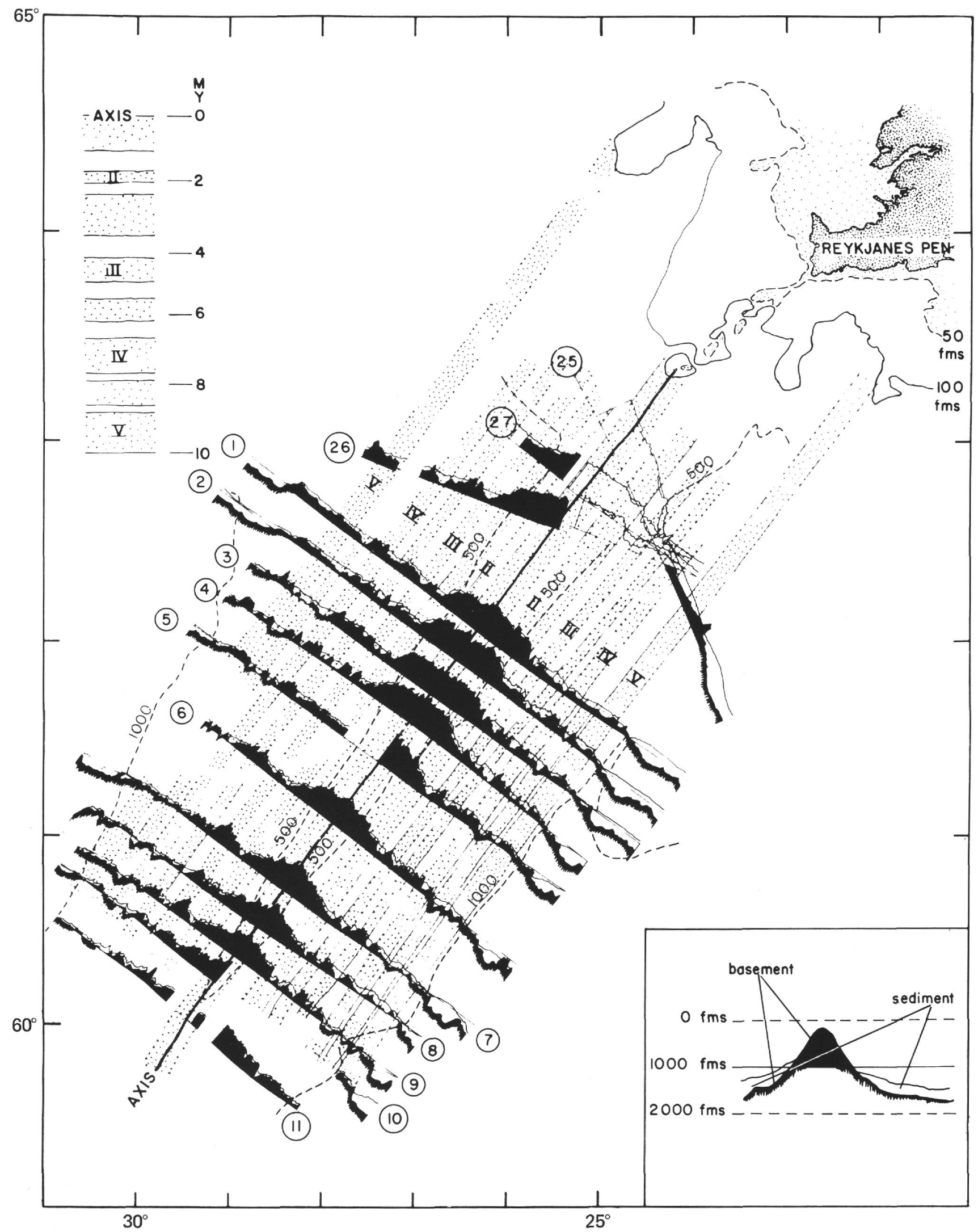

Figure 2. Bathymetric profiles over the Reykjanes Ridge (Talwani et al., 1971). 
The crestal depth ranges from $7 \mathrm{~km}$ to zero where it emerges at the coast of Iceland. Another distinguishing feature of the RER is that it continues for hundreds of kilometers without being offset a large distance by fracture zones. On the Mid-Atlantic Ridge (MAR), fracture zones occur at roughly 50 -km intervals.

Talwani et al. (1971) conducted an intensive geophysical reconnaissance of the RER. Their most significant inference may have been a 400-meter-thick highly magnetized crustal layer, which they believe is the source of the magnetic anomalies. Model studies show this layer to have an average intensity of $0.03 \mathrm{emu} / \mathrm{cm}^{3}$ (30 amps/meter) over the central anomaly, decreasing to $0.012 \mathrm{emu} / \mathrm{cm}^{3}$ (12 amps/meter) off the crestal region, and to $0.007 \mathrm{emu} / \mathrm{cm}^{3}$ ( $7 \mathrm{amps} / \mathrm{meters}$ ) over anomaly 5 . The anomaly amplitudes over the RER are very much larger than those commonly seen over the MAR. Although magnetic anomalies are particularly high over the crest, they seem to be relatively depressed here by a long-wavelength regional low.

The distribution of sediments over the RER is related to the regional topography and ocean circulation system. The crestal region (50 km wide) is almost devoid of sediments. Sediment thickness increases abruptly to 200 to 300 meters at anomaly $2^{\prime}$ just off the crestal plateau and again to several hundred meters beyond a regional depth offset at anomaly 5. A pronounced heat flow low $\left(0.2 \mathrm{cal} / \mathrm{cm}^{2} \mathrm{~s}\right.$, or 83.74 $\mathrm{mW} / \mathrm{m}^{2}$ ) occurs $75 \mathrm{~km}$ west of the RER axis (Talwani et al., 1971). This is near a negative magnetic anomaly between $4^{\prime}$ and 5 (about 7.5 million years old) and just east of Site 408 . Seismic refraction results show a velocity of $3 \mathrm{~km} / \mathrm{s}$ for the upper volcanic layer near the crest, which increases to about $4.6 \mathrm{~km} / \mathrm{s}$ on the flanks. The volcanic layer increases in thickness from 1.5 to $2.5 \mathrm{~km}$ flankward. Layer 3 velocities also increase flankward from 4.4 to $7.3 \mathrm{~km} / \mathrm{s}$. Either Layer $3 \mathrm{~B}$ or low-velocity mantle $(7.4$ to $7.6 \mathrm{~km} / \mathrm{s})$ occurs at 3.5 $\mathrm{km}$ sub-bottom at the RER crest and $4.5 \mathrm{~km}$ on the flanks. The RER is in isostatic equilibrium, but the crestal region has a positive free-air gravity anomaly of $50 \mathrm{mgal}$, similar to elsewhere on the MAR.

The RER volcanic layer is characterized by a distinctive petrochemistry (e.g., Schilling, 1973; Sun et al., 1975). Chemical gradients exist along the crest from Iceland to about $61^{\circ} \mathrm{N}$ (400 km to the south). South from Iceland, the pyroxene/plagioclase ratio, $\mathrm{Fe} / \mathrm{Mg}$, and wt $\% \mathrm{~K}_{2} \mathrm{O}, \mathrm{TiO}_{2}$, and $\mathrm{P}_{2} \mathrm{O}_{5}$, all decrease. In addition, rocks near Iceland are generally enriched in many trace elements with low solid/liquid partition coefficients (incompatible elements), relative to basalts more typical of the world's mid-ocean ridges. Schilling (1973) reported that this enrichment gradually disappears approaching $61^{\circ} \mathrm{N}$. Radiogenic $\mathrm{Sr}$ and $\mathrm{Pb}$ show higher concentrations near Iceland. In a study of lead isotopic gradients, Sun et al. (1975) show evidence which supports a mixing of mantle plume and asthenosphere material beneath Iceland to produce these geochemical gradients.

A thick sediment cover (200 to $500 \mathrm{~m}$ ) exists at Sites 407 and 408. Continuous coring was undertaken to answer questions relating to North Atlantic sedimentation, such as the history of glaciation, the effects of bottom currents on sedimentation, and the time of initiation of bottom circulation originating in the Norwegian Sea. Jones et al. (1970) discussed the flow of Norwegian Sea deep water southward over the Iceland-Faeroe Ridge and then along the east flank of the RER; from there it passes through the Gibbs fracture zone and then flows north, following the west flank of the RER. Several sediment ridges, including the Gardar Ridge on the east flank of the RER, have been formed as a result of this circulation. No sediment ridge is evident on the west flank of the RER. The sediments that are there, however, probably are materials the bottom current has carried in from elsewhere.

Site 410 is on the west flank of the MAR at latitude $45^{\circ} \mathrm{N}$, over anomaly 5 ( 9 to 10 million years old). Our objectives here were similar to those for other crestal sites. This particular region has been a subject of extensive survey work in the axial regions by the Bedford Institute and Dalhousie University (Aumento et al., 1971), and of several related studies by European institutions. The ridge here fits older notions of the MAR geology. It has a well-developed rift valley and mountains; slow spreading which is largely symmetrical, in contrast to the FAMOUS area $\left(37^{\circ} \mathrm{N}\right)$; thin sediment cover; classic MAR crustal structure (Layer 2A first was identified here); and isostatic compensation.

Sites 411,412 , and 413 are near $37^{\circ} \mathrm{N}$, within the FAMOUS area (Heirtzler and LePichon, 1974). The MAR here is at the juncture of the African and North American plates, and just south of the Azores and the North American-African-European triple junction (ridge-ridgefault). The MAR here trends $N 45^{\circ} \mathrm{E}$, and is composed of individual spreading segments about 40 to $50 \mathrm{~km}$ long, trending $\mathrm{N} 20^{\circ} \mathrm{E}$. These short segments are offset right laterally by fracture zones slightly oblique to the spreading segments. The spreading rate is about $1 \mathrm{~cm} /$ year for the last 10 million years (Phillips et al., 1975). On a shorter time scale, the spreading rates have differed on opposite sides of the ridge. For the last 1.7 million years the rate has averaged $1.34 \mathrm{~cm} /$ year to the east and $0.7 \mathrm{~cm} /$ year to the west. Before 1.7 million years B.P., the rates were $1.08 \mathrm{~cm} /$ year to the east and $1.33 \mathrm{~cm} /$ year to the west (Macdonald, 1977). The morphology of the ridge crest here has all the physiographic provinces defined by Heezen et al. (1959). The rift valley here is about $30 \mathrm{~km}$ wide, but the outer walls are about 20 $\mathrm{km}$ to the east of the valley axis and $10 \mathrm{~km}$ to the west (Macdonald et al., 1975). This asymmetric morphology reflects the asymmetry in spreading rates. On Leg 37, DSDP Sites 332 and 333 were drilled in the rift mountains, and Sites 334 and 335 were drilled on the high fractured plateau (Figure 3). The MAR morphology here obviously contrasts with that of the RER to the north. Sediment thickness increases rather uniformly away from the crest, from about 200 meters near Sites 332 and 333 (3.5 million years old) to 400 meters near Site 334 (8.9 million years old) to 500 meters near Site 335 (16.5 million years old). Refraction profiles were shot in the median valley and above 2-million-year-old crust on the west rift mountains (Poehls, 1975). These profiles define a low-velocity Layer $2 \mathrm{~A}(3.96 \mathrm{~km} / \mathrm{s})$ and Layers $2 \mathrm{~B}(5 \mathrm{~km} / \mathrm{s})$ and $3(7.2 \mathrm{~km} / \mathrm{s})$. Layer 2 may thicken from $1.5 \mathrm{~km}$ in the rift valley to $3 \mathrm{~km}$ at $15 \mathrm{~km}$ ( 2 million years old). High-velocity mantle was reported in the rift valley axis $(8.34 \mathrm{~km} / \mathrm{s})$. 


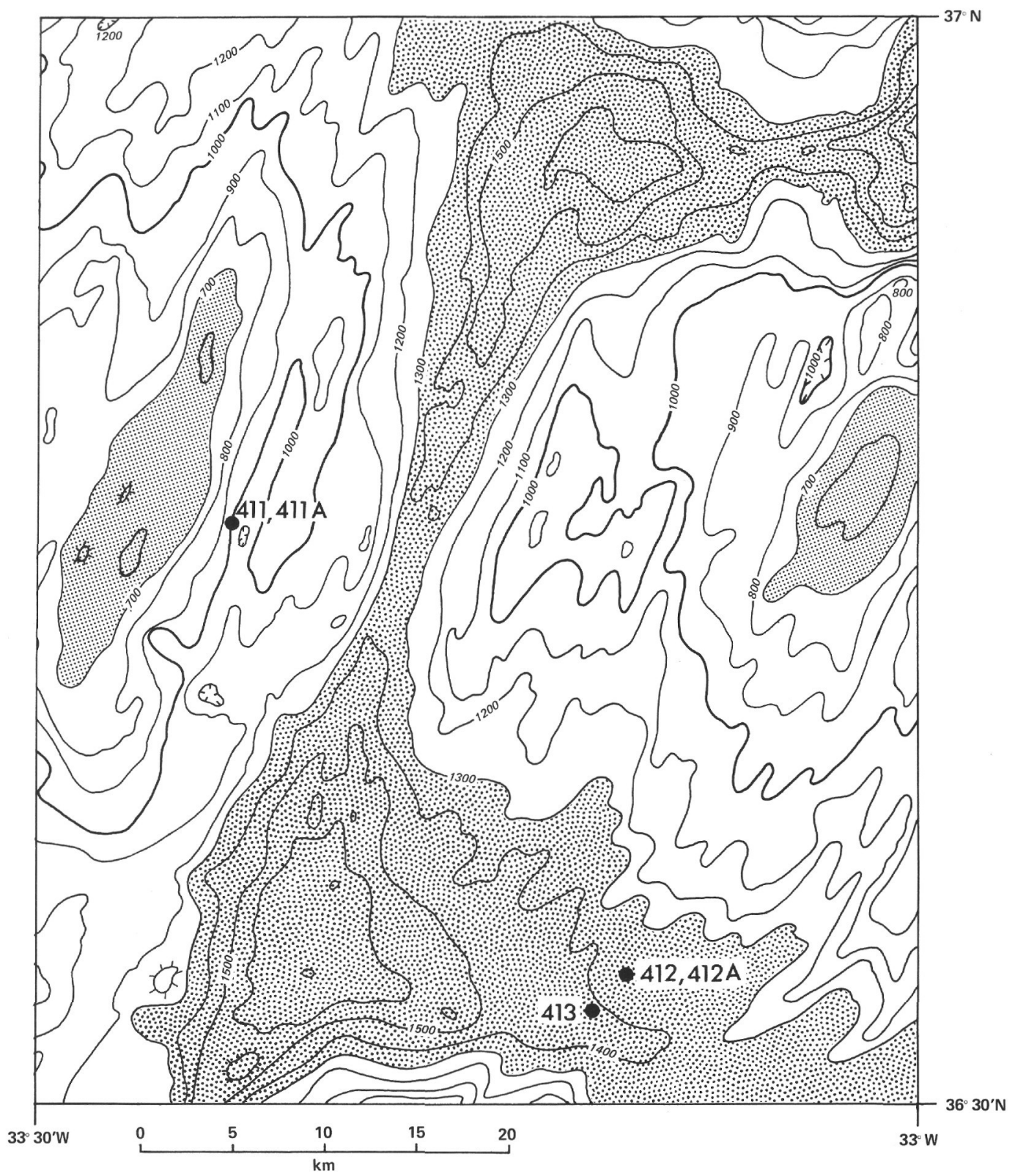

Figure 3. Leg 49 drill holes in the FAMOUS area.

Glomar Challenger left Aberdeen, Scotland on 18 July 1976 and docked 49 days later, on 4 September, at Funchal, Madeira. During the cruise, Glomar Challenger steamed 4275 miles and carried out operations at eight sites. We drilled 10 holes in water 832 to 2977 meters deep, and cut 192 cores, recovering a total of 441 meters (38\%) of Layer 1 and 163 meters (21\%) of Layer 2 (Table 1 and Figure 4). We also achieved the deepest single-bit penetration into Layer 2 (239 $\mathrm{m}$ at Site 409), penetrated a fracture zone valley (Sites 412 and 413), and drilled three holes in the youngest basement yet drilled $(409,411,412)$.

Leg 49 was plagued by an inordinate number of meteorological and medical difficulties, and was overclouded by the death, in a rig-floor accident, of Richard Meadows, a member of the drilling crew. We had to make three unscheduled calls at Reykjavik, Iceland, and finally had to abandon the final sites (413 and 414) as Hurricane Emmy, followed by Hurricane Frances, swept far into the central eastern Atlantic.

\section{EXPLANATORY NOTES}

\section{Organization}

The main body of this volume is in four sections. The first section discusses the overall aims of the cruise and reports on the drilling and findings at the individual sites. The second section deals with detailed presentation and discussion of our findings, both those carried out aboard ship and those undertaken ashore after the cruise. The third section integrates and summarizes our results for Leg 49 and presents the conclusions we have drawn. The final section is an appendix of tabulated data not otherwise included in this volume. 
TABLE 1

Drilling Results, Leg 49

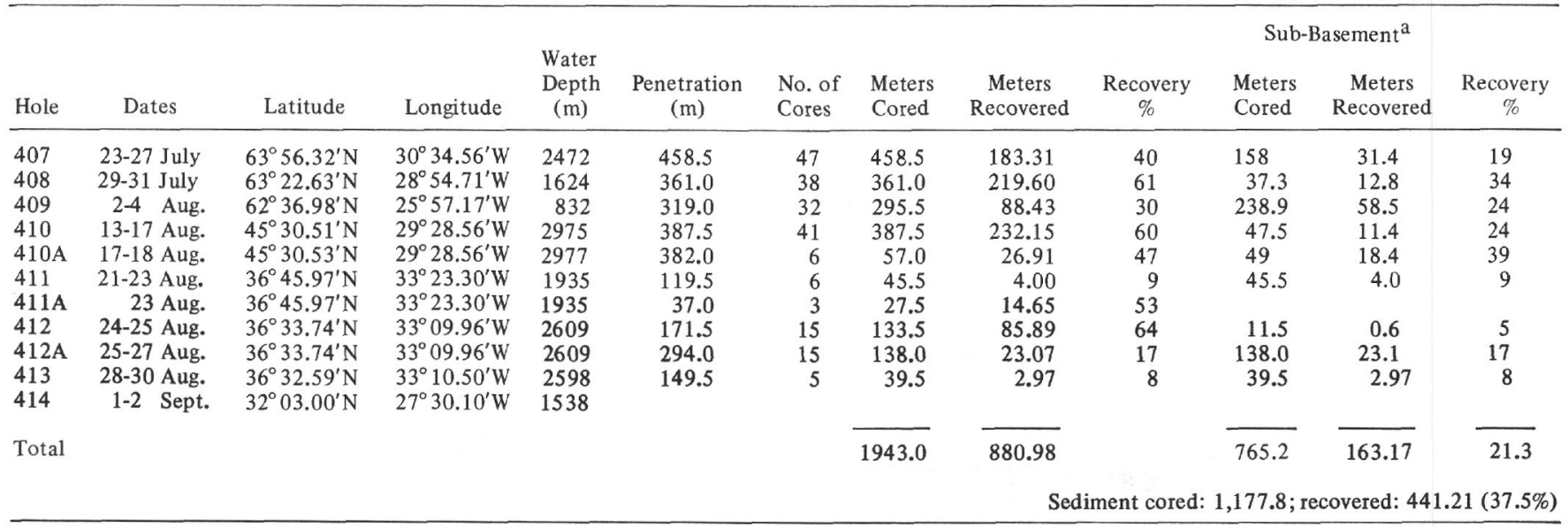

${ }^{a}$ Sub-basement statistics correspond to basaltic statistics. Sub-basement is used because of the frequency of interlayered sediment observed and inferred in subbasement drilling.

\section{Authorship}

Authorship of the site summary chapters is the shipboard scientific party collectively; the ultimate responsibility lies with the co-chief scientists. Chapters 3 through 9 present data and discussions for the holes drilled. All these chapters follow the general outline given below; primary authorship is listed in parentheses.

A. Site Summary Sheet (Cann: 407 through 410; Luyendyk: 411 through 414)

B. Background and Objectives (Cann: 407 through 410; Luyendyk: 411 through 414)

C. Operations (Luyendyk: 407 through 409; Cann: 410 through 414).

D. Sediments and Sedimentary Rocks

1. Lithostratigraphy (Roberts et al.)

2. Biostratigraphy (Poore et al.)

3. Physical Properties (Sharman et al.)

4. Paleomagnetism (Faller)

5. Chemistry (Wood)

6. Paleoenvironments (Shor, Steinmetz, et al.)

E. Basement Rocks

1. Lithostratigraphy (Duffield)

2. Igneous Petrography (Varet: 407 through 410; Vennum: 411 through 413)

3. Alteration Petrography (Cann)

4. Physical Properties (Sharman)

5. Paleomagnetism (Kobayashi et al.)

6. Interlayered Sediments (Roberts)

7. Chemistry (Wood)

F. Heat Flow (Kobayashi)

G. Summary (Cann: 407 through 409; Luyendyk: 410 through 413)

The interpretation of individuals have been retained in the parts of the report for which they were responsible, so conflicting interpretations sometimes occur within a site report. Authorship of chapters dealing with special topics in the second section and in the Synthesis section is cited in the text.

\section{Survey and Drilling Data}

Survey data crucial to site selection and hole positioning are presented in the various site reports. While steaming between sites, we took continuous profiles of depth, total magnetic field, and sub-bottom seismic reflections. Before dropping the beacon at a site, we made short surveys using a precision echo sounder, a seismic reflection profiler, and a proton precession magnetometer.

Underway depths were continuously recorded on an EDO-Western precision graphic recorder. The depths were read, in meters, with an assumed sound velocity of 1500 meters/second. The sea-floor depth, in meters, at each site, was corrected for variations in sound velocity (according to Matthews [1939]) and for the depth of the echo sounder transducer (6 meters). In addition, all depths referred to the drilling platform were calculated assuming 10 meters between the drilling platform and the water line.

The seismic reflection profiling system consisted of two Bolt airguns, a Scripps-designed hydrophone array, Bolt amplifiers, two bandpass filters, and two EDO dry-paper recorders; the two recording systems normally operated at different scales and filter settings. Copies of the underway data may be obtained from Barbara Long at DSDP, La Jolla.

Wide-angle reflection studies using free-floating SSQ-41A sonobuoys were conducted on Sites 407, 409, and 410. The results are presented in the site reports under "Correlation of seismic reflection and drilling results." The methods and assumptions employed are detailed in the Site 407 report.

\section{Shipboard Scientific Procedures \\ Core and Sample Identification}

DSDP drill sites have been numbered consecutively from the first site drilled from Glomar Challenger in 1968. Hole numbers are not identical with site numbers. A site number refers to holes drilled while the ship was positioned over one acoustic beacon. These holes could be within a radius as great as 900 meters from the beacon. 


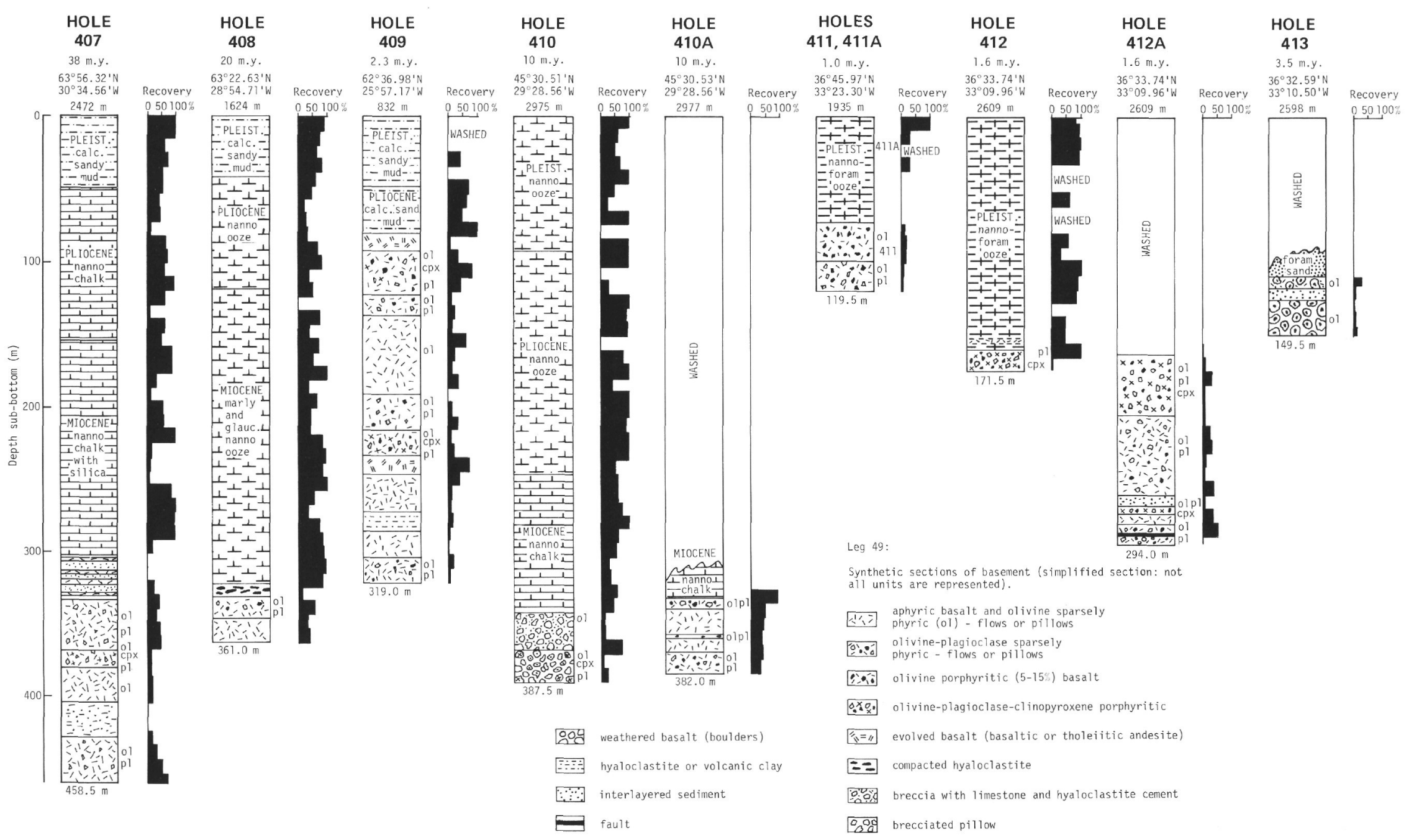

Figure 4. Leg 49 stratigraphy. Basement rocks are shown divided into petrographic units that usually encompass more than 1 flow unit. 
Several holes may be drilled at a single site, but only the first hole takes the site number. All additional holes at the same site are modified by a single letter suffix, added in alphabetical order. For example, the first hole at a site takes the site number; the second takes the site number with the suffix $\mathrm{A}$; the third, the site number with suffix B; and so forth. It is important, for sampling purposes, to distinguish between different holes drilled at the same site, since recovered sediments or rocks from different holes generally do not come from equivalent stratigraphic positions.

The cored interval is measured in meters below the sea floor, and is defined by the depth (below the sea floor) at which the coring operation was begun and that which it was finished. Generally, a cored interval is 9.5 meters long, the nominal length of a core barrel, although cored intervals may be shorter or even longer (rare).

\section{Drilling Characteristics}

In zones of low or zero recovery, the only information on the materials being drilled is the rate of penetration. This rate is not only inversely proportional to the hardness of the material being drilled, but is also a function of several other variables, including bit weight and drill RPM, as recorded on the drilling recorder. Our detailed hypothetical basement lithostratigraphy, encompassing recovered rocks and layers of rapid penetration and low recovery, is based on the drilling characteristics, primarily penetration rate.

\section{Cores}

Serial "cored intervals" are not necessarily adjacent, but may be separated by "drilled intervals" without recovery. In soft sediment, this is accomplished by "washing down," drilling with core barrel in place but circulating water with sufficient pressure to wash the sediment out of the way of the bit and up the annulus between the drill pipe and the wall of the hole. If thin hard rock layers are present, or if pump pressure is insufficient, it is possible to get "spotty" sampling within the washed interval and thus to core an interval of greater than 9.5 meters. This is what occurred in Core 1, Hole 410A. Likewise, if recovery is expected to be low, it is possible to "overcore" an interval of more than 9.5 meters and recover less than 9.5 meters of material. This happened with Cores 42 and 43 at Hole 407.

Cores are numbered sequentially from the top down. Full recovery comprises 9.28 meters of sediment or rock in a plastic liner $(6.6 \mathrm{~cm}$ diameter $)$ and a short sample $(\leqslant 22 \mathrm{~cm})$ in the core catcher (a multifingered device at the bottom of the core barrel which prevents cored materials from sliding out). Cores are cut into 1.5-meter sections and numbered sequentially from top to bottom. Because the core barrel is 9.28 meters long rather than 9 meters, another segment may be recovered in addition to six 1.5-meter sections. This segment is designated the "7-section"'; it comprises whatever is "left over" at the bottom of the core after six 1.5-meter sections have been cut. Both the "7-sections" and core-catcher samples are split and described along with the remainder of the core. (Before Leg 43, these pieces frequently were not split or described.)

Recovery is often less than 100 per cent. In cases of partial recovery, if the sediment core is continuous, the recovered material is assigned to the top of the cored interval, and 1.5-meter sections - as many as needed to accommodate the length of core recovered - are numbered sequentially (starting with Section 1 at the top). Sections are cut starting at the top of the recovered material; hence, the "void" (which occurs when the recovered sediment is not evenly divisible by 1.5 ) comes at the bottom section. When recovery is partial, the original position. of recovered material in the cored interval is unknown, so we employ this convention for consistency and for convenience in data handling. If recovery is partial and core fragments are separated, and if shipboard scientists believe the fragments of sediment were not contiguous, the intervening spaces are noted as "void." Whether it is contiguous or not, the core-catcher sample is described in the visual core descriptions beneath the lowest section, and depth below sea floor is assigned on this basis. Core labeling is graphically depicted in Figure 5.

Samples are designated by the interval $(\mathrm{cm})$ from the top of the core section from which the sample was extracted. A full sample designation would consist of the following information:

Leg-site-hole-core number-section number-interval (cm from top of section)

49-410A-4-3, 122-124 cm designates a sample taken at
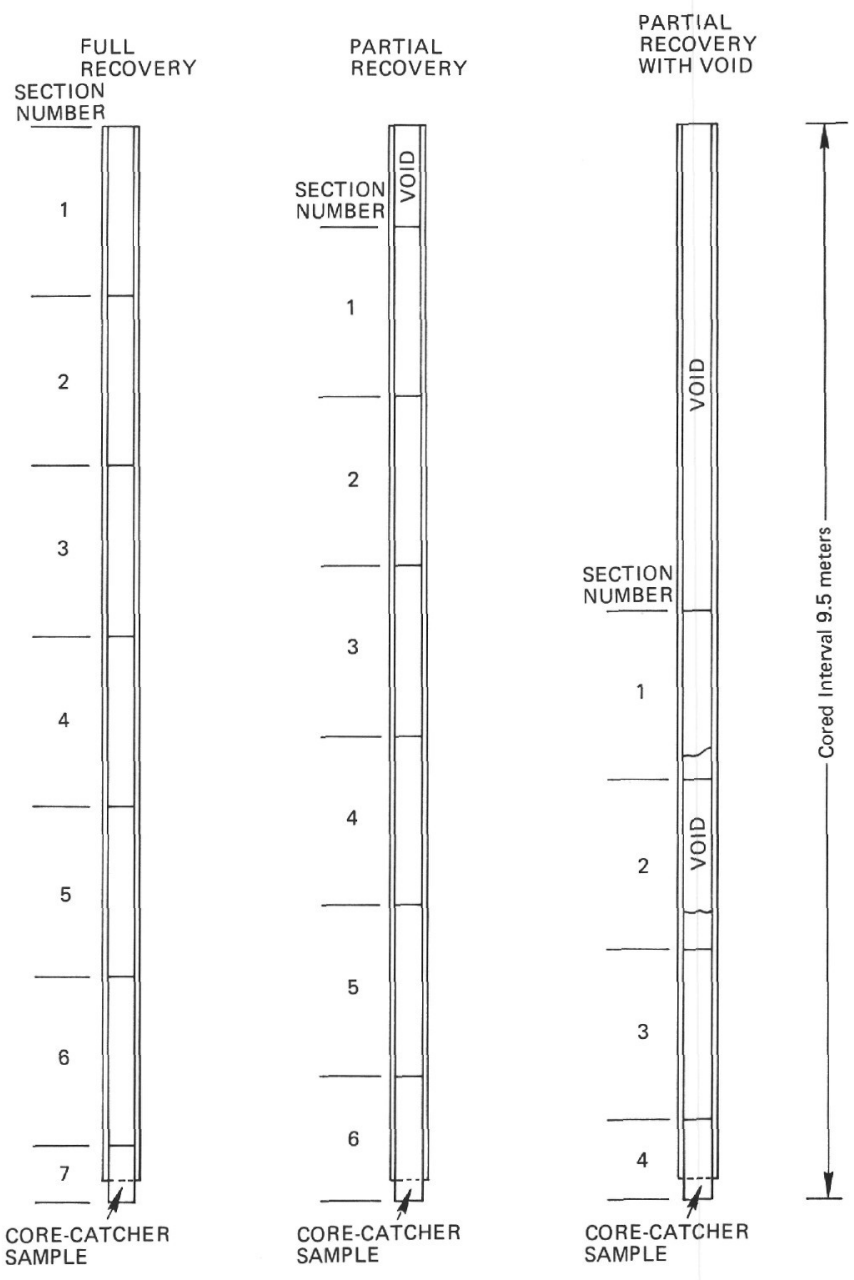

Figure 5. Labeling of sections for various kinds of recovery. 
122 to $124 \mathrm{~cm}$ from the top of Section 3 of Core 4 , from the second hole drilled at Site 410 during Leg 49. The depth below the sea floor for this sample would then be the depth to the top of the cored interval plus 3 meters for Sections 1 and 2, plus $122 \mathrm{~cm}$ (depth below the top of Section 3). For example, if the top of the cored interval were 100 meters, this would equal 104.2 meters. (Note that sample requests refer to a specific interval within a core section rather than level below sea floor.) A sample from the core catcher of this core is designated $410 \mathrm{~A}-4, \mathrm{CC}$.

\section{Core Handling}

The paleontologist makes initial assessment of core material from samples taken from the core catcher as soon as the core is brought aboard.

The core is cut into 1.5-meter sections, sealed, labeled, and moved into the core laboratory for processing. On Leg 49, conductivity measurements and standard gamma-ray attenuation porosity evaluation (GRAPE) analyses for bulk density and porosity were made on the unsplit core sections.

The cores are then split longitudinally into the "work" and "'archive"' halves. The archive half is described; color, texture, structure, and composition of the various lithologic units are noted on the standard visual core description forms. The archive half is then photographed and stored. Samples and measurements are taken from the working half. Samples include those for grain size, carbon-carbonate, water content, and paleontological determinations. Measurements on Leg 49 were primarily those of sonic velocity, on the split core with a Hamilton Frame velocimeter.

After sediment cores are sampled and described, they are maintained in cold storage aboard Glomar Challenger until they can be transferred to the DSDP East Coast Repository (Lamont-Doherty Geological Observatory, Palisades, New York).

The handling of hard rock material (e.g., basaltic rock) differs from that for sediment cores. The rocks are split with a rock saw into working and archive halves. The rocks are subdivided into pieces and given a sequential number starting from the core top. Each piece is separated by a styrofoam spacer (about one-half $\mathrm{cm}$ ) which subsequently adds length to the recovered core. The barrel sheets for hard rock cores (see below) differentiate between recovered length and storage length.

The archive half is described, photographed, and stored in the half-liners enclosed in shrink-tubing. The working half is sampled for measurements of paleomagnetism and sonic velocity (same sample) and water content, and for thin-sections and geochemistry. (All geochemical work was done in shore laboratories, and is presented in tabular form in the Appendix.)

All hard rocks recovered on Leg 49 are stored at the DSDP East Coast Repository.

\section{Procedures Used in the Measurement of Physical- Chemical Properties and in Sediment Analysis}

\section{Physical Properties}

A thorough discussion of physical procedures is given by Boyce (1973); only a brief review is offered here.
The physical properties are presented in graphic form and discussed in each site chapter. Explanation of some measuring techniques and data processing follows.

1) Sediment water content (W) is defined as the weight of water in the sediment divided by the weight of the saturated wet sediment.

2) Sediment porosity $(\phi)$ is defined as the volume of pore space divided by the volume of the wet-saturated sample, and expressed as per cent. The continuous plots of porosity (site summaries only) are obtained from the GRAPE densities (see below), assuming a mean grain density of $2.67 \mathrm{~g} / \mathrm{cm}^{3}$ and a water density of $1.024 \mathrm{~g} / \mathrm{cm}^{3}$.

3) Wet bulk density $(\rho)$ is defined as the weight per volume in $\mathrm{g} / \mathrm{cm}^{3}$ of the wet-saturated sediment, i.e.,

$$
\rho=\frac{\text { weight of wet sediment }}{\text { volume of wet sediment }\left(\mathrm{cm}^{3}\right)}
$$

4) Compressional wave velocity: The sonic velocity is obtained by timing a $400-\mathrm{kHz}$ sonic pulse across two transducers and measuring the distance across the sample with a dial gage (Hamilton Frame method). Measurements were made at laboratory pressure.

5) Thermal conductivity: The thermal conductivity is defined as the quantity of heat transmitted, consequent to unit temperature gradient, in unit time in steady conditions in a direction normal to a surface of unit area.

Thermal conductivities were measured with a von Herzen-Maxwell needle probe, using an improved instrumentation system developed by Woods Hole Oceanographic Institution.

Thermal conductivity can be estimated from water content by Ratcliffe's formula:

$$
\begin{aligned}
\text { Thermal conductivity } & =\frac{1}{\text { thermal resistance }} \\
& =\frac{1}{(168 \pm 14)+(6.78 \pm 0.31) \mathrm{W}}
\end{aligned}
$$

where $\mathrm{W}$ is water content in weight per cent.

Measurements of conductivity and water content at Sites 407,408 , and 410 are compatible with this.

6) Heat flow: Heat flow measurements were made in situ in the sediment sections at Sites 407, 408, and 410. The upward heat-flow measurements were computed from the temperature of the sediment measured at depth, using the downhole instrument (DHI) developed at Woods Hole Oceanographic Institution. The instrument was mounted within the core barrel, which was lowered to the hole depth.

\section{Geochemical Measurements}

Aboard ship, analyses for $p \mathrm{H}$, alkalinity, chlorinity, $\mathrm{Ca}^{++}, \mathrm{Mg}^{++}$, and salinity are conducted routinely.

1) $p \mathrm{H}: p \mathrm{H}$ is determined by a flow-through electrode method; a small portion of unfiltered pore water is passed through a glass capillary electrode.

2) Alkalinity: Alkalinity is measured by a colorimetric titration of a $1-\mathrm{ml}$ aliquot of interstitial water with $0.1 \mathrm{~N}$ $\mathrm{HCl}$, using a methyl red/blue indicator.

$$
\text { Alkalinity }(\mathrm{meq} / \mathrm{kg})=(\mathrm{ml} \mathrm{HCl} \text { titrated }) \cdot(97.752)
$$


3) Salinity: Salinity is calculated from the fluid refractive index as measured by a Goldberg optical refractometer, using the ratio

$$
\text { Salinity }(\% 00)=(0.55) \cdot \Delta \mathrm{N}
$$

where $\Delta \mathrm{N}=$ refractive index difference $\times 10^{4}$. Local surface seawater is regularly examined by each of the above methods for reference.

\section{Sedimentologic Analyses}

1) Carbonate analysis (shipboard determination) was by the "Karbonat Bombe" technique of Müller and Gastner (1971). In this procedure, the powdered sample is treated with $\mathrm{HCl}$ in a closed cylinder. Resulting $\mathrm{CO}_{2}$ pressure is proportional to $\mathrm{CaCO}_{3}$ content. Error can be as low as 1 per cent for sediments high in $\mathrm{CaCO}_{3}$, and in general an accuracy of \pm 2 to \pm 5 per cent can be obtained.

2) Carbon-carbonate: The (DSDP) carbon-carbonate data were determined by a LECO induction furnace combined with a LECO acid-base semi-automatic carbon determinator. Step-by-step procedures are in Volume 4 of the Initial Reports of the Deep Sea Drilling Project, and the method, calibration, and precision are discussed in Volume 9.

3) Grain size: Grain-size distribution was determined by standard sieving and pipette analysis. Step-by-step procedures appear in Volume 5 of the Initial Reports. In general, the sand-, silt-, and clay-sized fractions are reproducible within \pm 2.5 per cent (absolute), with multiple operators over a long time. A discussion of this precision is present in Volume 9 of the Initial Reports.

\section{Measurements of Paleomagnetism}

\section{Apparatus and Procedure}

The apparatus available on Leg 49 consisted of a Digico balanced fluxgate magnetometer, a horizontal long-core spinner, and an alternating field (AF) demagnetization unit, all used on the previous cruise, and a Schonstedt thermal demagnetization unit, not previously used on the ship.

Digico engineers came on board in Aberdeen to service the spinner, computers, and teletype. Three specimens brought by M. Steiner were measured and found to have components, intensities, and directions of magnetization very similar to those obtained formerly in on-shore laboratories using two different Schonstedt spinner magnetometers. Frequent checks showed noise intensity levels to be less than $0.07 \mu \mathrm{G}\left(7 \times 10^{-8} \mathrm{emu} / \mathrm{cm}^{3}\right)$, integrated over $2^{5}$ spins, and less than $0.02 \mu \mathrm{G}\left(2 \times 10^{-8}\right.$ $\mathrm{emu} / \mathrm{cm}^{-3}$ ) over $2^{7}$ spins.

We decided not to use the long-core spinner for the following reasons: the long-core spinner gives no indication of the vertical component of the magnetization, which is the most important at high latitudes; we anticipated (correctly) that the cores would consist of wet-soft sediments or broken basalts, neither of which would be suitable for measurements at closely spaced intervals along the length; with the thermal demagnetizer in position, laboratory space was restricted; and an unfavorable evaluation of the usefulness of the long-core spinner was recorded on Leg 48 .

The Schonstedt TSD-1 thermal demagnetization unit was assembled within its mu-metal shielding cylinder. The chamber was demagnetized using the degaussing ring and a variac. The heater is powerful enough to raise the specimens to the required temperature in a few minutes, and the specimens are usually kept in the heating chamber for five minutes after that temperature is reached. All the specimens undergo thermal treatment in air. A volcanic rock from the Canary Islands was thermally demagnetized and then allowed to acquire a TRM in the laboratory (Figure 6). The acquired TRM (TRM2) was then demagnetized and a third TRM acquired in the lab (TRM3). This test shows the oxidative effects of the thermal demagnetizing process.

\section{Sampling and Presentation}

As usual, the specimens were in the form of $1^{\prime \prime} \times 1^{\prime \prime}$ cylindrical mini-cores, each with an orientation arrow on the top flat face to indicate the up-hole direction. This arrow is therefore the fiducial line referred to in the Digico manual, and it points in the direction of the positive $\mathrm{x}$-component of magnetization. The positive y-component is perpendicular to $\mathrm{x}$ in the plane of the flat face and directed to the right, and the positive $\mathrm{z}$-component lies along the axis of the mini-core directed away from the oriented flat face. To restore the measured magnetic vector to its original direction, the bedding correction in the Digico program is used to carry out a $90^{\circ}$ rotation.

\section{Lithologic Classification, Nomenclature, and Symbols \\ Sediment Classification}

The sediment classification scheme used on Leg 49 is, with minor modification, that devised by the JOIDES Panel on Sedimentary Petrology and Physical Properties and adopted for use by the JOIDES Planning Committee in March, 1974. The scheme is as follows.

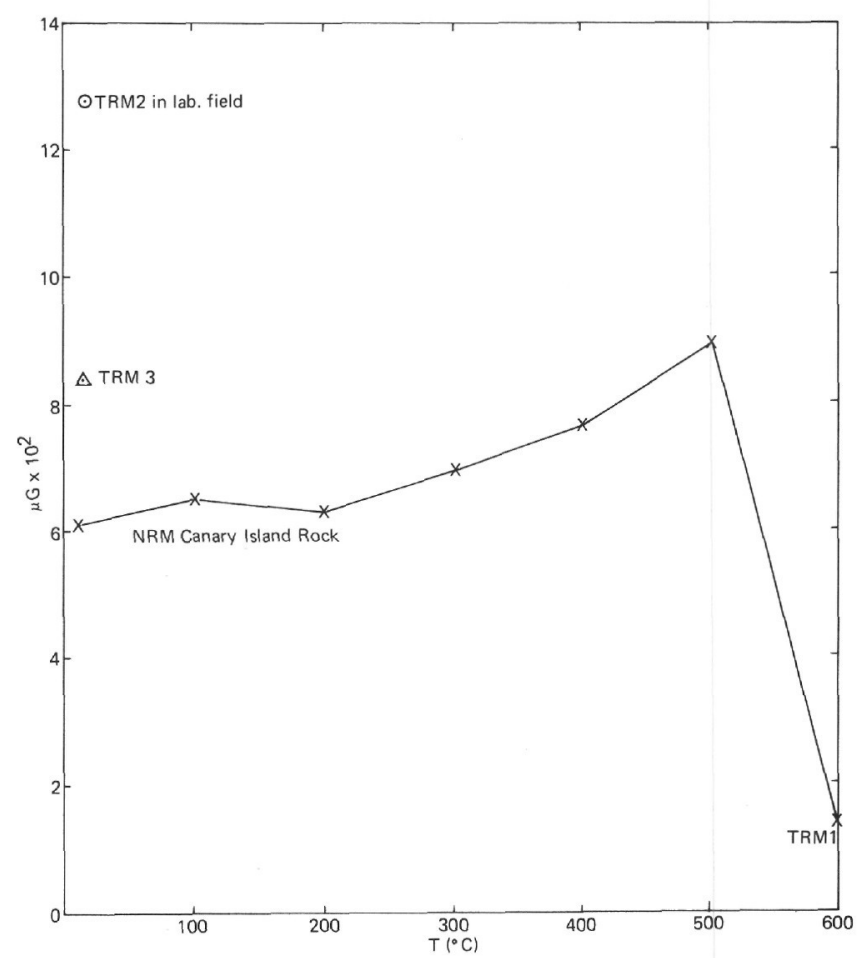

Figure 6. Test of Schonstedt TSD-1 Thermal Demagnetizer. 
A. Sediment assumes only the names of those components present in quantities greater than 10 per cent.

B. Where more than one component is present, the most abundant component is listed farthest to the right, and other components are listed progressively to the left in order of decreasing abundance.

C. Induration is indicated in the sediment name. Although the determination of induration is highly subjective, the following criteria provide a useful guide.

\section{Terrigenous sediments}

If the material is soft enough that the core can be split with a wire cutter, only the sediment name is used (e.g., silty clay, sand).

If the core must be cut on the band saw or diamond saw, the suffix "stone" is added (e.g., silty claystone, sandstone).

2. Biogenic sediments

Ooze: soft, with very little strength and readily deformed with a spatula blade.

3. Volcanogenic sediments

Pyroclastic rocks are described according to the textural and compositional scheme of Wentworth and Williams (1932). The textural groups are

$>32 \mathrm{~mm}$ : volcanic breccia

$<32 \mathrm{~mm}$ : volcanic lapilli

$<4 \mathrm{~mm}$ : volcanic ash (tuff, indurated)

Compositionally, these pyroclastic rocks are described as vitric (glass), crystalline, or lithic.

4. Pelagic clay

$>10 \%$ authigenic components

$<30 \%$ siliceous microfossils

$<30 \%$ calcareous microfossils

$<30 \%$ terrigenous components

5. Biogenic calcareous sediments

$>30 \%$ calcareous microfossils

$<30 \%$ terrigenous components

$<30 \%$ siliceous microfossils

Principal components are nannofossils and foraminifers. Qualifiers are used as follows:

\section{Percentage of \\ Foraminifers}

Name

$<10$ : nannofossil ooze (chalk, limestone)

10-25: foraminifer-nannofossil ooze (chalk, limestone)

25-50: nannofossil-foraminifer ooze (chalk, limestone)

$>$ 50: foraminifer ooze (chalk, limestone)

Chalk: firm, partly indurated calcareous ooze; or friable limestone readily scratched with a fingernail or edge of spatula blade.

Limestone: hard, cemented, or recrystallized calcareous rocks.

Radiolarite, diatomite, spiculite: hard, cemented biogenic siliceous ooze.
D. The class limits of the sediment classification system are based on percentages of components, as given below.

1. Terrigenous sediments

$>30 \%$ terrigenous components

$<30 \%$ calcareous microfossils

$<10 \%$ siliceous microfossils

$<10 \%$ authigenic components

Sediments in this category are subdivided into textural groups according to the relative proportions of sand, silt, and clay. The size limits are those defined by Wentworth (1922). Textural classification follows the triangular diagram of Shepard (1954) (Figure 7).

If $\mathrm{CaCO}_{3}$ is 10 to 30 per cent, "calcareous," "nannofossil," or the like is used as a qualifier. Other qualifiers (e.g., feldspathic, glauconitic) are used for components present in quantities greater than 10 per cent.

If the sediment contains more than 50 per cent $\mathrm{CaCO}_{3}$ of unknown origin, it is calcareous ooze.

Calcareous sediments containing 10 to 30 per cent siliceous fossils are qualified by "radiolarian," “'diatomaceous,'” or "siliceous," depending upon the type of siliceous component.

See also Item 8 (Special Rock Types), for more detailed limestone classification.

2. Biogenic siliceous sediments

$>30 \%$ siliceous microfossils

$<30 \%$ calcareous microfossils

$<30 \%$ terrigenous components

Radiolarians > diatoms / sponge spicules: radiolarian ooze (radiolarite).

Diatoms > radiolarians/sponge spicules: diatom ooze (diatomite).

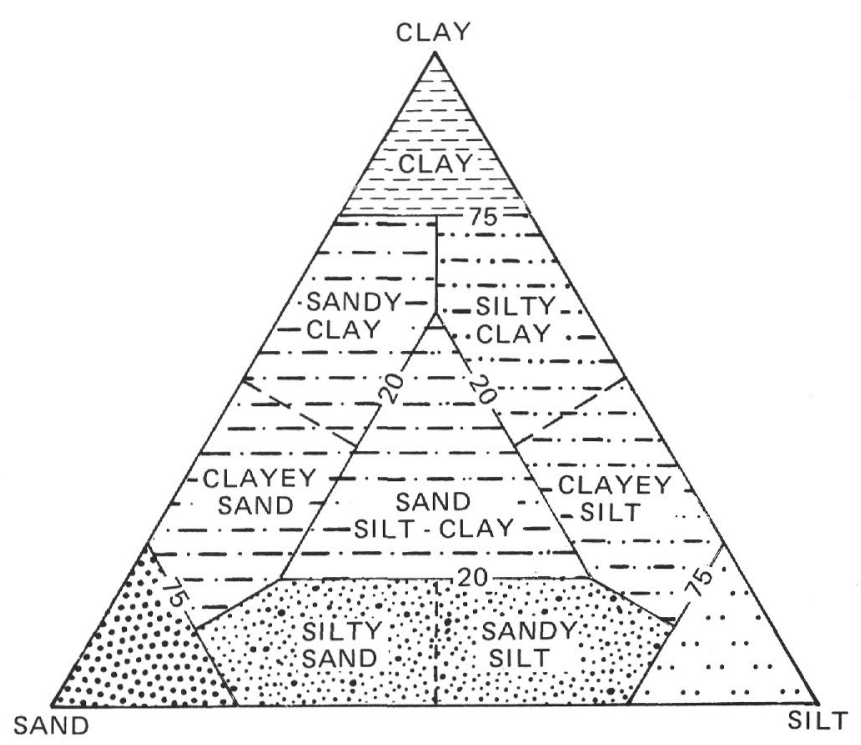

Figure 7. Textural classification of clastic sediments (after Shepard, 1954). 
When mixed, or siliceous microfossil source unidentified: siliceous ooze.

Amorphous lithified silica: porcellanite, chert.

Siliceous sediments containing 10 to 30 per cent $\mathrm{CaCO}_{3}$ are qualified by "nannofossil,", "foraminifer," "calcareous," "nannofossilforaminifer," or "foraminifer-nannofossil,", depending on kind and quantity of $\mathrm{CaCO}_{3}$ component.

3. Transitional terrigenous/biogenic calcareous sediments

$>30 \% \mathrm{CaCO}_{3}$

$<30 \%$ terrigenous components

$<30 \%$ siliceous microfossils

"Marly" is used as a qualifier for transitional sediments in the biogenic calcareous series (e.g., "marly nannofossil ooze").

If 10 to 30 per cent siliceous microfossils, appropriate qualifier is used (e.g., "diatomaceous marly chalk").

4. Transitional terrigenous / biogenic siliceous sediments

$>10 \%$ siliceous microfossils

$<30 \%$ terrigenous components

$<30 \% \mathrm{CaCO}_{3}$

10 to 30 per cent siliceous microfossils: (name of siliceous fossil) mud or mudstone (e.g., 10 to $30 \%$ radiolarians: radiolarian mudstone).

30 to 70 per cent siliceous microfossils: muddy (name of siliceous fossil) ooze or (name of siliceous fossil) (e.g., 50\% diatoms: muddy diatom ooze).

If 10 to 30 per cent $\mathrm{CaCO}_{3}$, appropriate qualifier is used (e.g., calcareous muddy radiolarite).

5. Special rock types:

We applied Folk's (1968) classification of limestones, based on depositional texture, to the lime-cemented basalt breccias recovered at Sites 410, 410A, 412A, and 413. Frequently used terms are defined as follows:

a. Micrite: lithified microcrystalline calcite ooze with individual particles less than $4 \mu \mathrm{m}$ in diameter.

b. Intraclast: a lump of reworked micrite eroded and redeposited at nearly the same location; generally greater than $2 \mathrm{~mm}$ in diameter.

\section{Symbols}

Figure 8 presents a key to lithologic symbols, and to sedimentary structure symbols. When complex lithologies occur, the percentage occurrence of each lithology is represented by a system of vertical bars (Figure 9).

For constituents present in amounts of 2 to 10 per cent, a letter or symbol designation procedure can be applied. This entails using the capital letters and symbols shown below.

$\mathrm{F}=$ Foraminifers

$\mathrm{D}=$ Diatoms

$\mathrm{R}=$ Radiolarians

$\mathrm{A}=$ Ash
$\mathrm{G}=$ Glauconite

$\mathrm{S}=$ Sponge Spicules

$\mathrm{P}=$ Pyrite

$\mathrm{V}=$ Volcanic Fragments

These letters and symbols will be sparsely printed over the regular lithologic symbols.

\section{Color}

Color notations are based on the standard Munsell or GSA color charts. Colors recorded on the visual core descriptions were determined during shipboard examination immediately after the core sections were split.

\section{Smear Slides}

Most mineral identifications made on board ship were based on inspection of smear slides. Mineral abundances were determined by per cent of smear slide area covered by each constituent. Past experience has shown that abundances so determined may be accurate to within one per cent or so for very distinctive minor constituents; but accuracy of \pm 10 to 20 per cent is considered very good for major constituents. Smear-slide estimates are recorded as percentages.

On the barrel sheet descriptions, the sample interval is designated by two numbers: section number and $\mathrm{cm}$ below top of section.

\section{Biostratigraphy}

Biostratigraphic age determinations are based on examination of core-catcher samples. The zonation of Blow (1969) is used for planktonic foraminifers and the zonation of Martini (1971) is used for calcareous nannofossils. The Cenozoic time scale of Berggren (1972) is used to construct sediment accumulation rates.

\section{Magnetostratigraphy}

Site locations are often described in relation to the location of marine magnetic anomalies. In such cases, estimates of basement age are given by employing the magnetic time scale of LaBrecque et al. (1977). In the individual shore-lab reports of Part III, authors may have used other time scales at their preference.

\section{Core Disturbance and Downhole Contamination}

Unconsolidated sediments are often disturbed by the rotary drilling and coring technique. Bedding contacts in cores may be slightly bent (slightly disturbed) or so extensively bent that the bedding planes are near vertical (highly disturbed). And in extreme cases, bedding may be completely disrupted to produce a "drilling slurry."

Consolidated sediments and rocks seldom show much internal deformation, but are usually cracked and sometimes extensively fragmented. Adjacent pieces in the the section and intervening sediment may have been lost. In extreme cases (drilling breccia), pieces have completely lost their original orientation and stratigraphic position.

Symbols used on the core descriptions to depict various types of drilling disturbance are shown on Figure 10.

Downhole contamination results when sediment, lithic fragments, manganese nodules, chert, and pebbles are washed or dragged downhole and become incorporated into 


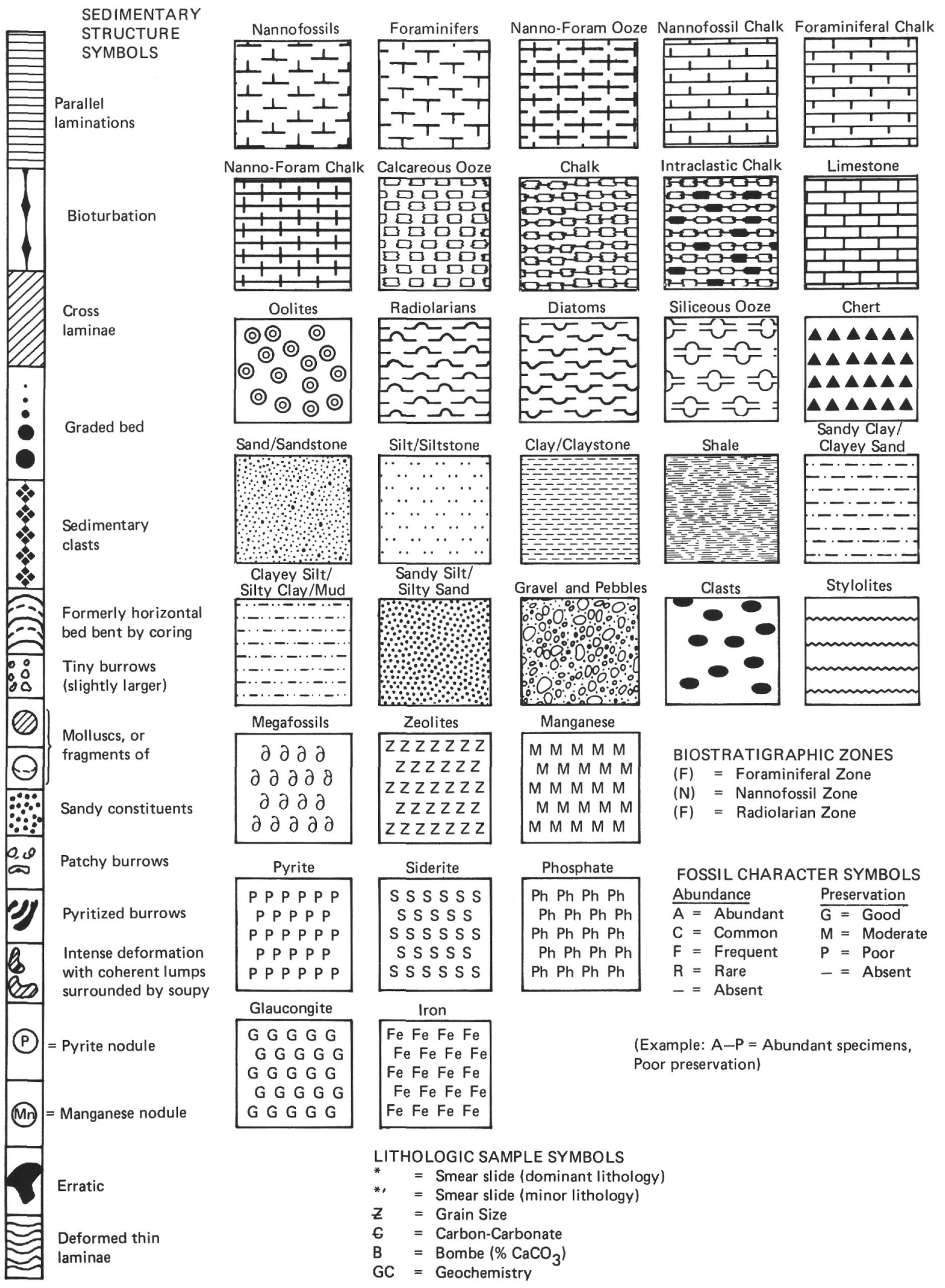

Figure 8. Key to sedimentary lithologic and biostratigraphic symbols. 


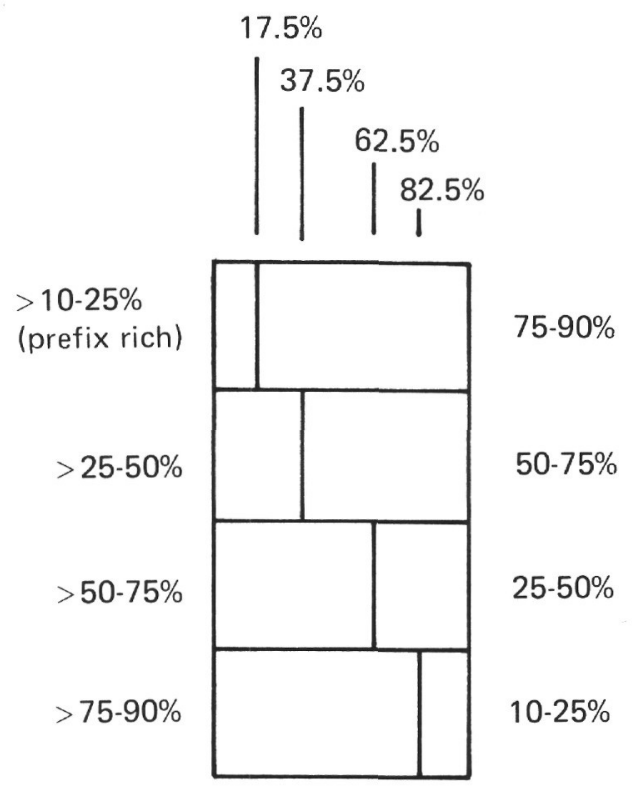

Figure 9. Vertical bar width representation of class limits in graphic lithology.

cores at levels far below their proper stratigraphic position. Displaced sediment and rock fragments are frequently difficult to recognize; known downhole contaminants are, however, recorded on the core descriptions.

\section{Basement Description}

Visual core description forms for igneous and metamorphic rocks are not the same as those used for sediments. The sediment barrel sheet forms are substantially those published in previous Initial Reports. Igneous rock representation on barrel sheets is too compressed to provide adequate information for potential sampling. To aid in planning sampling programs we have included chemical analyses in the Appendix. Figure 11 shows graphic symbols used in the barrel sheet figures for the individual site reports. Summary lithologic columns shown throughout the volume use the graphic symbols in Figure 12.

\section{Igneous and Metamorphic Rock Classification}

Basalt, gabbro, and breccia were recovered on Leg 49. Classification is based mainly on mineralogy and texture. Thin-section work in general added no new information to the hand specimen classification.

Basalts are termed aphyric, sparsely phyric, moderately phyric, or phyric, depending on the proportion of phenocrysts visible with the binocular microscope $(\sim 12 \times)$. Aphyric basalts are so called if phenocrysts are absent. For practical purposes, this means that if one piece of basalt was found with a phenocryst or two in a section where all other pieces lack phenocrysts, and no other criteria such as grain size or texture distinguish this basalt from the others, then it too is described as aphyric. A note of the rare phenocrysts is included in the general description, however. This approach enables us to restrict the number of lithologic units to those with clearly distinctive and persistent visual differences.

Sparsely phyric basalts are those with 1 to 2 per cent phenocrysts present in almost every piece of a given core or section. Clearly contiguous pieces without phenocrysts are included in this category, again with the lack of phenocrysts noted in the general description.

Moderately phyric basalts contain 2 to 10 per cent phenocrysts. Aphyric basalts within a group of moderately phyric basalts are separately termed aphyric basalts.

Phyric basalts contain more than 10 per cent phenocrysts. No separate designation is made for basalts with more than 20 per cent phenocrysts; the proportion indicated in the core forms should be sufficient to guide the reader.

The basalts are further classified by phenocryst type, preceding the terms phyric, sparsely phyric, etc. A plagioclase-olivine moderately phyric basalt contains 2 to 10 per cent phenocrysts, most of them plagioclase, but with some olivine.

An unusually high degree of vesicularity occurs in Hole 409 rocks (as much as $38 \%$ ). In other holes, vesicularity is generally less than 10 per cent. The vesicularity symbol (Figure 11) is used where the percentage of vesicles exceeds 10.

In igneous rock, each core description or barrel sheet indicates the frequency and location of samples for various analyses. Thin-section locations are denoted by an " $X$,' as are major-element X-ray fluorescence samples analyzed by H. Bougault and B. Zolotarev. For physical properties, " $G$ " denotes a GRAPE determination and "WC", a water content sample. Sonic velocity results are also listed. Results of magnetic studies are indicated, but data are given for only one sample per section. The inclination and intensity values quoted are those for the stable direction upon AF demagnetization.

\section{REFERENCES}

Aumento, F., Loncarevic, B., and Ross, D.I., 1971. Hudson geotraverse: geology of the Mid-Atlantic Ridge at $45^{\circ} \mathrm{N}$, Phil. Trans. Roy. Soc., Sec. A., v. 268, p. 623-650.

Berggren, W.A., 1972. A Cenozoic time-scale - some implications for regional geology and paleobiogeography, Lethaia v. 5, p. 195-215.

Blow, W.H., 1969. Late middle Eocene to Recent planktonic foraminiferal biostratigraphy. In Bronnimann, P. and Renz, H.H. (Eds.), Proceedings of First Planktonic Conference: Leiden (E.J. Brill), p. 199-422.

Boyce, R.E., 1973. Physical properties - methods. In Edgar, N.T., Saunders, J.B., et al., Initial Reports of the Deep Sea Drilling Project, v. 15: Washington (U.S. Government Printing Office), p. 1115-1127.

Folk, R.L., 1968. Petrology of sedimentary rocks: Austin (Hemphills).

Heezen, B., Tharp, M., and Ewing, M., 1959. The floors of the oceans, I. The North Atlantic; Geol. Soc. Am. Spec. Paper 65, p. 122

Heirtzler, J.R. and LePichon, X., 1974. FAMOUS: A plate tectonics study of the genesis of the lithosphere; Geology, v. 2, p. 273-274.

Jones, E., Ewing, M., Ewing, J., and Eittreim, S., 1970. Influences of Norwegian Sea overflow water on sedimentation in the northern north Atlantic and Labrador Sea, J. Geophys. Res., v. 75, p. 1655-1680.

LaBrecque, J., Kent, D., and Cande, S., 1977. Revised magnetic polarity time scale for Late Cretaceous and Cenozoic time, Geology, v. 5, p. 330.

Macdonald, K.C., Luyendyk, B.P., Mudie, J.D., and Spiess, F.N., 1975. Near-bottom geophysical study of the 


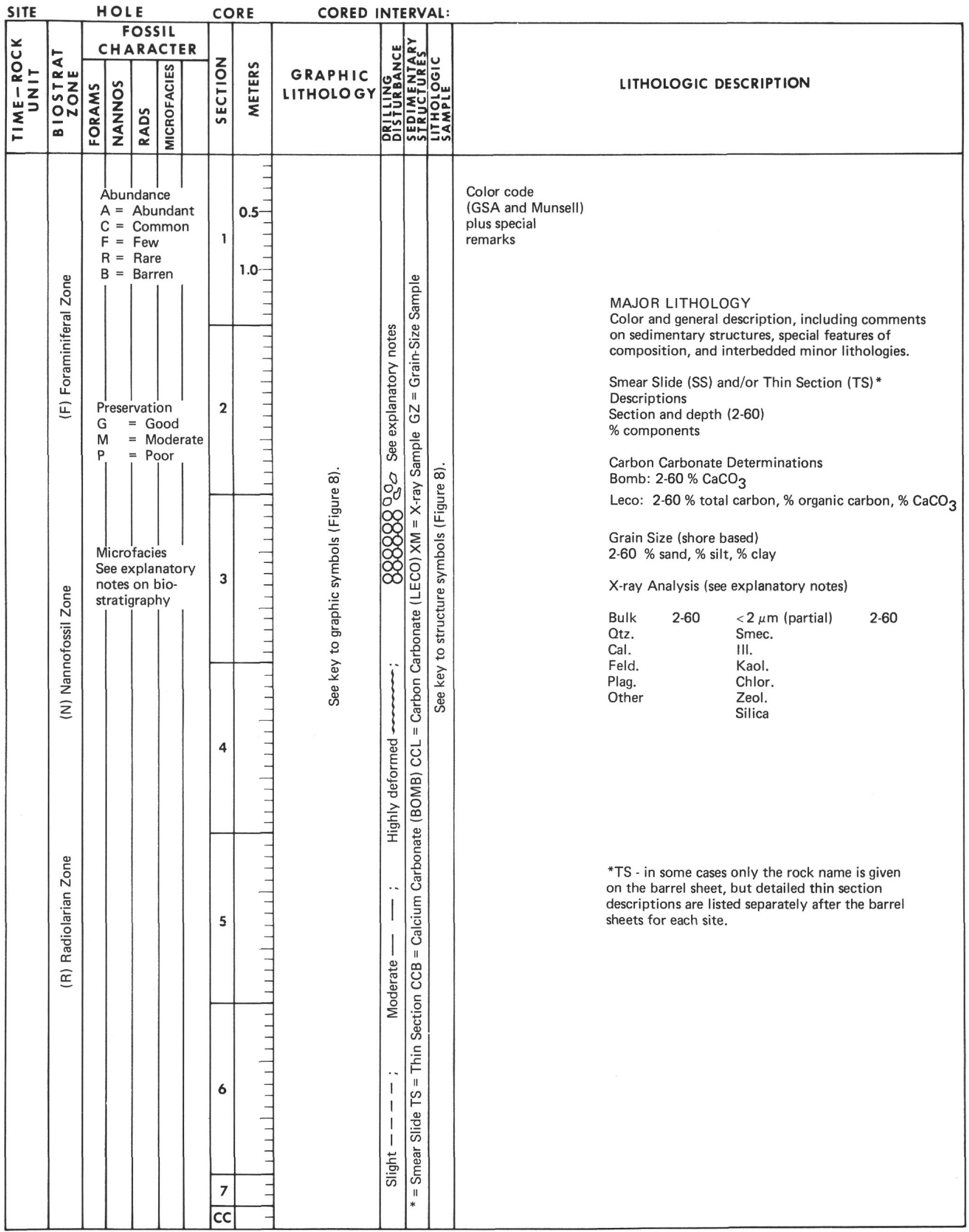

Figure 10. Sample core description. 
Mid-Atlantic Ridge Median Valley near latitude $37^{\circ} \mathrm{N}$ : Preliminary observations, Geology, v. 3, p. 211-215.

Macdonald, K.C., 1977. Geomagnetic reversals and the deep drill hope at DSDP Site 332, J. Geophys. Res., v. 81, p. 4163-4165.

Martini, E., 1971. Standard Tertiary and Quaternary calcareous nannoplankton zonation. In Farinacci, A. (Ed.), Proceedings of Second Planktonic Conference: Roma (E. Tecnoscienza), p. 739-785.

Matthews, T., 1939. Tables of the velocity of sound in pure water and sea water for use in echo-sounding and sound ranging: London (Admiralty Hydrographic Department).

Müller, G. and Gastner, M., 1971. The "'Karbonat-Bombe," a simple device for the determination of the carbonate content in sediments, soils and other materials, $N$. Jb. Miner. Mh., v. 10, p. 466-469.

Phillips, J.D., Fleming, H.S., Feden, R., King, W.E., and Perry, R., 1975. Aeromagnetic study of the Mid-Atlantic Ridge near the Oceanographer Fracture Zone, Geol. Soc. Am. Bull., v. 86, p. 1348-1357.

Poehls, K., 1975. Seismic refraction on the Mid-Atlantic Ridge at $37^{\circ}$ N, J. Geophys. Res., v. 79, p. 3370-3373.

Schilling, J.G., 1973. Iceland mantle plume: Geochemical study of Reykjanes Ridge, Nature, v. 242, p. 565-571.

Shepard, F.P., 1954. Nomenclature based on sand-silt-clay ratios, J. Sediment. Petrol., v. 24, p.151-158.

Sun, S., Tatsumoto, M., and Schilling, J.G., 1975. Mantle plume mixing along the Reykjanes Ridge axis: Lead isotope evidence, Science, v. 190, p. 143-147.

Talwani, M., Windisch, C., and Langseth, M., 1971. Reykjanes Ridge Crest: A detailed geophysical study, J. Geophys. Res., v. 76, p. 473-517.

Wentworth, C.K., 1922. A scale of grade and class terms of clastic sediments, J. Geol., v. 30, p. 377.

Wentworth, C.K. and Williams, H., 1932. The classification and terminology of the pyroclastic rocks, Rept. Comm. Sedimentation, Bull. Nat., Res. Covnc., no. 80, p. 10-53.

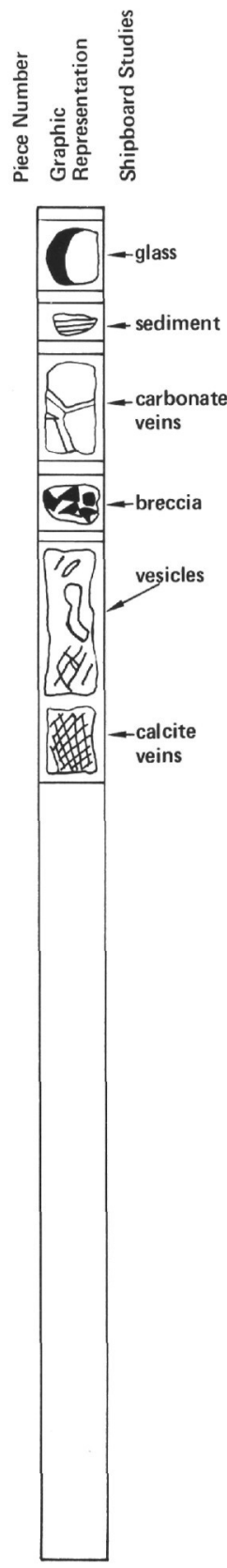

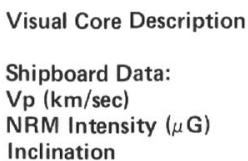

Code for shipboard studies:

$\mathrm{X}=\mathrm{X}$-ray flourescence and $\mathrm{CHN}$ chemical analysis

$T=$ Thin section

WC $=$ Water content

$\mathrm{G}$ = GRAPE determination

Figure 11. List of symbols, igneous rock, Leg 49. 

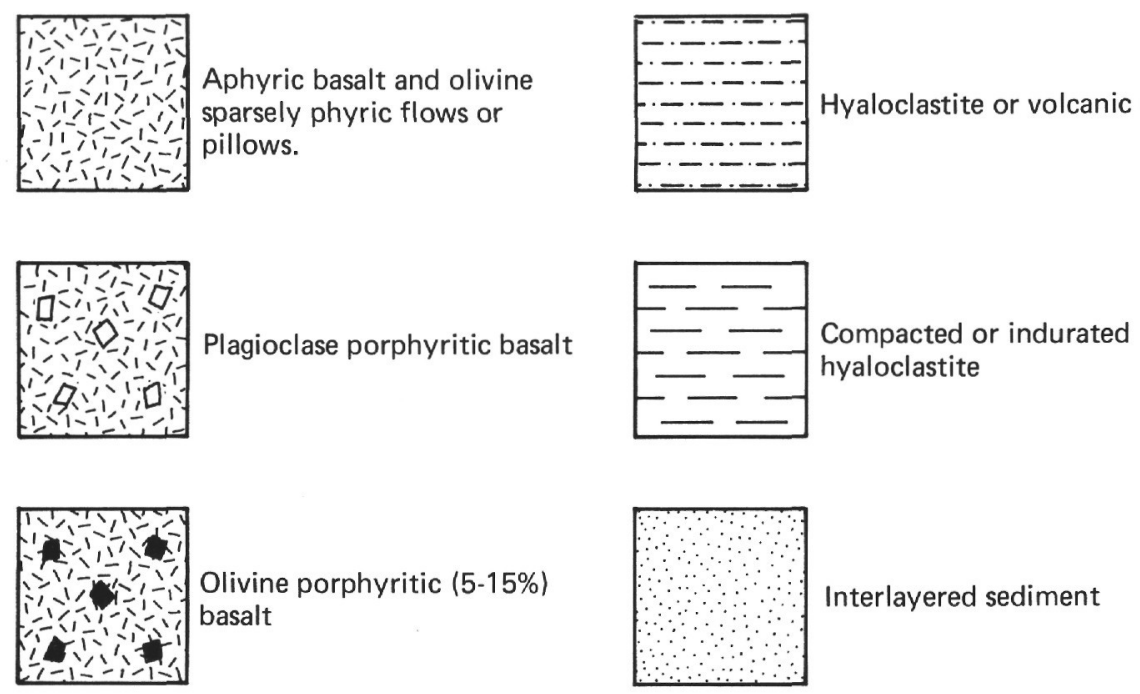

Interlayered sediment

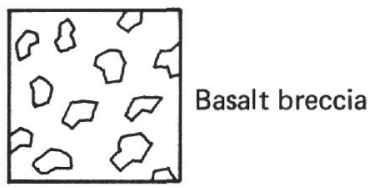

Olivine-plagioclase sparsely phyric flows or pillows
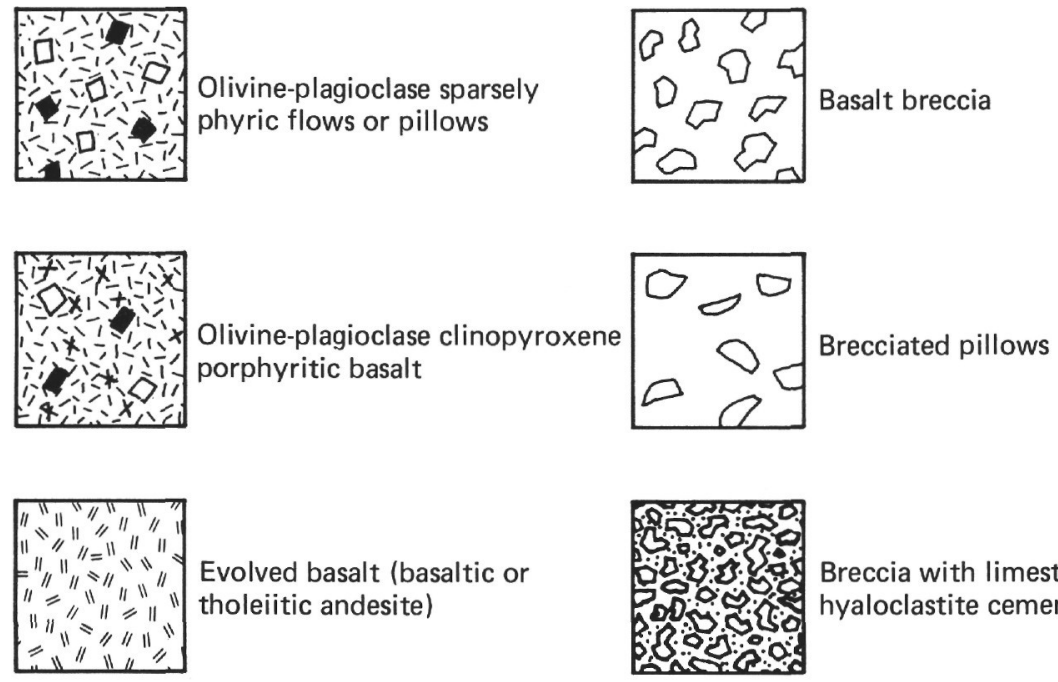

Breccia with limestone and hyaloclastite cement

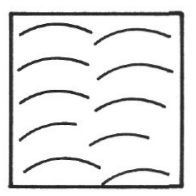

Pillow basalt

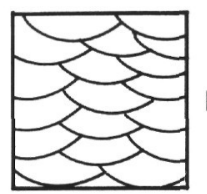

Pillow basalt

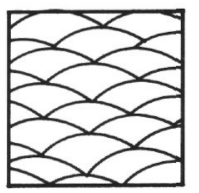

Pillow basalt
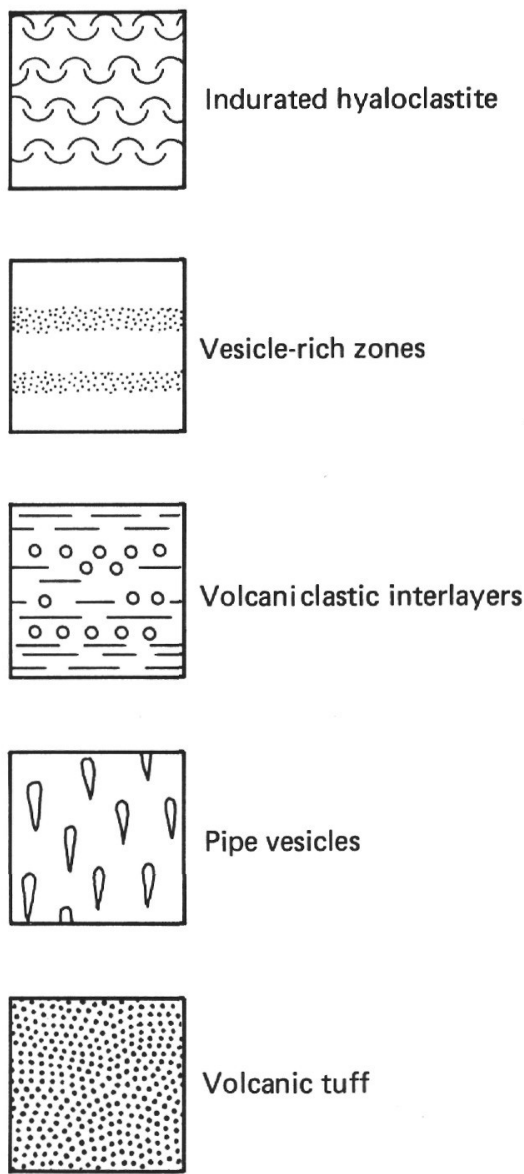

Used in site reports and various chapters of Parts II and III. 